\title{
The Rights of Non-Muslims in an Islamic State
}

\author{
Rudi \\ Institut Agama Islam Darussalam (IAID) Ciamis, Jawa Barat \\ Email: rudi.gandana@iaid.ac.id \\ Yaman Suryaman \\ Institut Agama Islam Darussalam (IAID) Ciamis, Jawa Barat
}

\begin{abstract}
ABSTRAK
Artikel ini berusaha mengkaji tentang kedudukan dan hak warga negara non Muslim di sebuah negara Islam. Hasil kajian ditemukan bahwa orangorang non Muslim dipandang sebagai warga negara oleh negara Islam, sekalipun mereka adalah bukan penduduk asli negeri itu. Keadilan Islam dan prinsip kesetaraan dalam Islam menuntut agar orang Kristen, Hindu, Budha, Melanesia, Turki, atau Arab harus diperlakukan sama seperti warga negara lainnya di dalam negaranya sendiri. Ia berhak menikmati hak istimewa yang sama sebagai warga negara tanpa memandang afiliasi religiusnya.
\end{abstract}

\begin{abstract}
This article seeks to examine the position and rights of non-Muslim citizens in an Islamic country. The study results found that non-Muslims are seen as citizens by an Islamic state, even though they are not natives of that country. Islamic justice and the principle of equality in Islam require that Christians, Hindus, Buddhists, Melanesians, Turks, or Arabs be treated the same as other citizens in their own country. He is entitled to enjoy the same privileges as a citizen regardless of religious affiliation.
\end{abstract}

Keywords: Non Muslim rights, Islamic state, justice

\section{INTRODUCTION}

Recently a number of books have been written on the rights of nonMuslims who have to live under the rule of Islamic law. Most of these books present things that seem good from an Islamic point of view, without revealing the negative sides of these laws. 
This short study attempts to examine these laws as stated by the 4 schools of Fiqh (jurisprudence). This study aims to awaken readers to the negative implications of these laws without ignoring the more tolerant views of modern reformers. It is our deep hope that this study will reveal to our readers the real truth on both the positive and negative sides.

An Islamic state is essentially an ideological state, and therefore radically different from a national state. This statement made by Mawdudi provides the basic foundation for the political, social, economic and religious systems of all Islamic countries that enforce Islamic law. This ideological system intends to discriminate against people according to their religious group. Mawdudi, who is a prominent Pakistani Muslim scholar, summarizes the basic differences between an Islamic state and a secular state as follows:

1) The Islamic State is an ideological state. The population is divided into Muslims, i.e. those who believe in the ideology of the country and nonMuslims, i.e. those who do not believe in the ideology of the state.

2) The responsibility for the policy and administration of such a state "is primarily in the hands of those who believe in Islamic ideology". Therefore, non-Muslims cannot be asked to implement or be trusted to take responsibility for policy making.

3) An Islamic state must distinguish (exactly: discriminate) between Muslims and non-Muslims. But Islamic law, namely Sharia, guarantees non-Muslims "certain rights which restrict them from getting involved in the affairs of the state because they do not recognize the ideology of the state". When they embrace Islam, they "become equal participants in all matters relating to the state and government" (Al-Maududi, 1990:71).

The view above comes from Hanafiah, one of the schools of Islamic jurisprudence. The other three schools of thought are Malikiah, Hanbiliyah (the strictest and most fundamental of all), and Salafi. The four schools of thought dogmatically agree on the basis of their acknowledgment of Islamic faith in their interpretation of Islamic law which comes from 4 sources, namely:

a) Qur'an (read or spoken), namely: the holy book of the Muslim community which contains direct quotations from Allah believed to be dictated by Jibril. 
b) Hadith (narrative), namely: a collection of Islamic traditions which include the words and deeds of Muhammad as heard by his companions, first, second and third hand.

c) Al-Qiyas (analogy or comparison), namely: legal decisions taken by Islamic jurists based on cases that have existed before.

d) Ijma' (consensus), namely: the interpretation of Islamic law given through the consensus of prominent Muslim scholars in a particular country (Al-Maududi, 1990:72).

The textual laws listed in the Qur'an are few. There are doors wide open for eminent scholars to give Fatwas (legal opinions) based on the Qur'an, Hadith, and other Islamic disciplines, as we shall see later. Classification of non-Muslims: In his article entitled "The Ordinances of the People of the Covenant and the Minorities in an Islamic State," Sheikh Najih Ibrahim Ibn Abdullah suggests that jurists classify non-Muslims or infidels into two categories, namely: Dar-ul-Harb or House of War, which is imposed on non-Muslims who are not bound by a peace treaty, or treaty, and whose blood and property are not protected by the laws of retaliation or retaliation; and Dar-us-Salam or House of Peace, namely those who fall into the following 3 classifications:

a) Zimmis/dhimmis (detained persons) i.e. conquered non-Muslims who live in Muslim countries and agree to pay Jizya (taxes) for protection and security, and are subject to Islamic law. These people enjoy a permanent agreement.

b) The Hudnas (peaceful) are the people who signed a peace treaty with the Muslims after they were defeated in the war. They may remain in their country, but are subject to Islamic legal jurisprudence like the Dhimmis, on the condition that they are not allowed to wage war against Muslims.

c) Musta'min (protected people) are people who come to an Islamic country as envoys, traders, visitors, or students who want to learn about Islam. The Musta'min were not allowed to fight the Muslims and were not obliged to pay the Jizya, but they were urged to embrace Islam. If he does not want to embrace Islam, he is allowed to return to his country safely. Muslims are forbidden to harm him in any way. When he returned to his own country, he was treated as a person from the House of War. 


\section{Islamic Law and the Dhimmi}

The Muslim Muftis (legal authorities) agree that contracts with the Zimmis should be given primarily to the People of the Book, i.e. Christians and Jews, then to Magis or Zoroastrians. However, they disagree on whether any contracts should be signed/made with other groups such as atheists or communists. The Hanbali and Salafi groups believe that it is not permissible to enter into agreements with people who are godless or people who do not believe in God Almighty. The Hanbali and Maliki groups assert that Jizya is acceptable to all disbelievers, regardless of their belief and belief in God. However, Abu Hanifa did not want the pagan Arabs to have this choice because they were the same nation/people as the Prophet. They were only given 2 choices: accept Islam or be killed (Al-Maududi, 1990:76).

Jizya literally means punishment. Jizya is a protection tax levied on non-Muslims living under the Islamic regime, which confirms their legal status. Mawdudi stated that "acceptance of the Jizya establishes the sanctity of their life and property, and therefore neither the Islamic state, nor the Muslim public may interfere with their property, honor or freedom". Paying the Jizya is a symbol of humiliation and submission because the Dhimmis are not seen as citizens of an Islamic state even though they are, in most cases, natives of that country.

Such an attitude alienated the Dhimmis from being an important part of the community. How can a Dhimmi feel at home in his own homeland, among his own people, and with his government, when he learns that the Jizya he pays is a symbol of humiliation and submission? In his book entitled The Islamic Law Maintaining to non-Muslims, Sheikh `Abdulla Mustafa Al-Muraghi mentions that Jizya can only be abolished from a Dhimmi if he becomes a Muslim or dies. The Salafi group insists that Jizya is not automatically removed when a Dhimmi converts to Islam. The exclusion of Jizya has become a kind of incentive to encourage the Dhimmis to renounce their faith and embrace Islam.

Sheik Najih Ibrahim Ibn Abdulla summed up the purpose of Jizya. He says, quoting Ibn Qayyim al-Jawziyya, that the Jizya was instituted: ...to protect the blood (of the Zimmis), as a symbol of contempt for the disbelievers and as ridicule and punishment against them, and as the Salafis put it, Jizya given as compensation/payment for living in an Islamic 
country." Then Ibn Qayyim added, "Since all religions belong to Allah, (Jizya) aims to insult the unbelievers and their followers, and ridicule them. Implementing Jizya against the followers of disbelief and oppressing them is required by Allah's religion. The Qur'anic text confirms this understanding when the Qur'an says 'until they pay the jizya obediently while they are in a state of submission' (Sura 9:29). The contradiction with this is to let the disbelievers enjoy their glory and practice their religion as they please so that they can have power and authority.

\section{The Dhimmis and Religious Practices}

Muslims believe that the Zimmis are polytheists because they see belief in the Trinity as belief in three Gods. They claim that Islam is the only true religion. Therefore, in order to keep Muslims from going astray, especially from the unpardonable sin, i.e. shirk (polytheism), the practice is prohibited among Muslims, as it is seen as a great abomination. When Christians practice it openly, it becomes a temptation and a call to apostasy. It is important to note here that according to Muraghi, the Dhimmis and the disbelievers are polytheists and therefore should receive the same treatment (Muraghi, 1998:43).

According to Islamic jurists, the following legal provisions should apply to the Dhimmis (Christians as well as Jews) living among Muslims:

a) Dhimmis are not allowed to build new churches, temples or synagogues. They are allowed to renovate old churches or existing houses of worship, they are not allowed to add any new construction. "Old churches" are church buildings that existed before the Islamic conquest and were included in the peace treaties drawn up by the Muslims. Building any church, temple, or synagogue in the Arabian Peninsula (Saudi Arabia) is prohibited. It was the land of the Prophet and only Islam could exist there. However, Muslims, if they wished, were allowed to destroy all non-Muslim houses of worship in any land they conquered.

b) The Zimmis are not allowed to pray or read their holy books aloud at home or in church, lest Muslims hear their prayers.

c) The Dhimmis are not allowed to print their religious books or sell them in public places or in markets. They were allowed to publish it and sell it among themselves, in their churches and their temples.

d) The Dhimmis are not allowed to put a cross in their homes or churches because the cross is a pagan symbol. 
e) Dhimmis are not allowed to broadcast or perform their religious rituals on radio or television or use the media to publish pictures of their religious ceremonies in newspapers and magazines.

f) The Dhimmis are not allowed to gather in the streets for their religious celebrations; however, each of them had to walk quickly to their church or temple.

g) The Dhimmis are not allowed to become soldiers unless there is an urgent need for them in which case they are not allowed to occupy leadership positions, but they are only seen as assassins/mercenaries.

Mawdudi, who is a member of the Hanafiah, shows a more friendly opinion towards Christians. He said: In their cities, they are permitted to do so (their religious practice) with complete freedom. However, in areas where the population is purely Muslim, Islamic governments have the full right to impose restrictions on their practices if deemed necessary (Al-Maududi, 1990:89)

Apostasy means rejecting Islam, either by action or by words. "Therefore apostasy means that person is ending his involvement with Islam". When a person rejects the fundamental creeds of Islam, he rejects the faith, and this is apostasy. In Islam such an act is seen as a very big sin. Quran says:

How will Allah show a people who disbelieve after they have believed, and they have acknowledged that the Messenger (Muhammad) is truly a messenger, and evidence has come to them? Allah does not point out the wrongdoers. For them, the recompense is: that the curse of Allah befalls them, (as well as) the curse of the angels and all of mankind, they abide in it, their punishment will not be lightened, nor will they be given respite. Except those who repent, after (unbelievers) and make corrections. For verily Allah is Forgiving, Most Merciful (Surah 3:86-89).

Basically, Islamic law obliges Muslims not to force the Zimmis to embrace Islam. It is the duty of every Muslim to demonstrate the virtues of Islam so that non-Muslims will embrace Islam voluntarily after discovering the greatness and truth of Islam. Once a person becomes a Muslim, he cannot turn back. If he turns away from Islam, he will first be warned, then he will be given 3 days to think and repent. If he persisted in his apostasy, his wife had to divorce him, his property confiscated, and his children taken from him. He was not allowed to remarry. Instead, he should be brought to justice and sentenced to death. If he repents, he can return to his wife and 
children or remarry. According to the Hanafiah group, an apostate woman is not allowed to marry. He had to spend time meditating to return to Islam. If he does not repent, he will not be put to death, but he must be persecuted, beaten and imprisoned until he dies. Other sharia schools demanded that he be put to death. The above punishment is described in a Hadith recorded by Bukhari: "It was reported by 'Abaas...that the Messenger of Allah...said, 'Whoever changes his religion (from Islam to another religion), kill him" (AlMaududi, 1990:91).

In his book entitled Shari ah: The Islamic Law, Doi stated, “The death penalty in the case of apostasy has been mutually agreed upon by the four schools of Islamic jurisprudence" (Doi, 1984:103). A non-Muslim who wants to become a Muslim is encouraged to do so, and anyone, even his parents who try to stop his intention, can be punished. However, whoever makes an attempt to convert a Muslim to another religion will also be punished.

\section{Civil Laws}

The Dhimmis and Muslims are subject to the same civil laws. They should be treated equally in respect of honor, theft, adultery, murder and destruction of property. They should be punished according to Islamic law even though they have different religious beliefs. The Dhimmis and Muslims alike are subject to Islamic law in civil business matters, financial transactions such as sales, leases, firms, establishment of securities companies, mortgages and contracts. For example, theft is punished by cutting off the thief's hand, whether he is a Muslim or a Christian. But with regard to privileges, the Dhimmis do not get the same treatment. For example, the Dhimmis do not get permission to carry weapons.

A Muslim man can marry a Dhimmi girl, but a Dhimmi man cannot marry a Muslim girl. if a woman embraces Islam and wants to get married, her non-Muslim father has no authority to hand her over to the groom. It must be handed over by a Muslim wali.

If one of the parents is a Muslim, then the children must be raised Muslim. if the father is a Dhimmi and his wife embraces Islam, the wife must divorce him; then she has custody of her children. Some fundamentalist schools argue that a Muslim husband has the right to lock his Dhimmi wife in his house and forbid her from going to pray in his house of worship. 
The Hanafis believe that both the Dhimmis and the Muslims should be given the same punishment for the same crime. If a Muslim intentionally kills a Dhimmi, then he too must be killed. The same applies to a Christian who kills a Muslim. But other schools of law have different interpretations of Islamic law. The Salafists are of the view that a Muslim who kills a Dhimmi should not be killed, because it is inappropriate to equate a Muslim with a polytheist (Mushrik). In such cases, blood money must be paid. The sentence imposed depends on which school of law is used by the Islamic state where the crime was committed. This illustrates the implications of different interpretations of Islamic law based on Hadith. Each school tries to document their legal opinion by referring to the Hadith or to an incident experienced by the Prophet or the Caliphs "who are properly guided".

The Dhimmis cannot testify against the Muslims. They can only testify against other Dhimmi or Musta'min. Their oath is not seen as valid in Islamic courts. Under Sharia, a Dhimmi does not even meet the requirements to be under oath. Muraghi emphatically said, "The testimony of a Dhimmi is not accepted because Allah - praise be to Him - says: 'God will not allow an infidel to raise his hand over the people'". A Dhimmi, who is seen as an infidel, cannot testify against any Muslim even if he has moral credibility. If a dhimmi has made false accusations against another Dhimmi and has been convicted, his credibility and integrity can no longer be accepted. One serious implication of this is, if a Muslim has committed a serious offense against a fellow Muslim, and was witnessed only by a Dhimmi, then the court will have difficulty settling the case because the testimony of the Zimmis is unacceptable. However, this same Dhimmi whose integrity is flawed, if he embraces Islam, then his testimony will be accepted both against other Dhimmis as well as Muslims, because according to Sharia, "By embracing Islam he has gained new credibility which allows him to testify.. All he has to do is pronounce the Islamic creed (shahada) in front of witnesses, and that will elevate him from the status of an outcast to a respected Muslim, and enjoy all the privileges that a pious Muslim has.

In private matters relating to marriage, divorce and inheritance, the Zimmis are allowed to submit them to their own religious courts. Every Christian denomination has the right and authority to determine the final outcome of each case. The Dhimmis are free to practice their religious and social ceremonies at home and in the church without state interference, even in such matters as drinking wine, raising pigs, and eating pork, provided 
they do not sell it to Muslims. In general, the Zimmis are denied the right to file their family, marriage, divorce and inheritance matters in Islamic courts. However, in the event that a Muslim judge agrees to take the case, the court must apply Islamic law.

An Islamic state is an ideological state, therefore the head of state must be a Muslim, because he is obliged to carry out sharia and administer state government based on the Qur'an and Sunnah. The function of his advisory board is to assist him in implementing Islamic principles and referring to these laws. People who do not profess Islamic ideology cannot become heads of state or council members.

Mawdudi, aware of the requirements of modern society, seems to be more tolerant of the Dhimmis. He said:

With regard to a modern parliament or legislature, and which is very different from an advisory council in the traditional sense, this rule can be relaxed to allow non-Muslims to become members as it is fully guaranteed in the constitution; so that no law that contradicts the Qur'an and Sunnah must be passed, so that the Qur'an and Sunnah become the main source of public law, and the head of government must be a Muslim (Al-Maududi, 1990:197).

In such circumstances, the extent of influence of non-Muslim minorities will be limited to matters relating to the general problems of the country or to the interests of minorities only. Their participation must not threaten the fundamental obligations of Islam. Mawdudi added, It is possible to establish separate representative councils for all non-Muslim groups in the capacity of a central agency. Membership and voting rights of such a council would be restricted to non-Muslims and they would be given complete freedom within its framework.

These views do not get the approval of many other Shariah schools which argue that non-Muslims are not allowed to occupy any position that would give them authority over Muslims. A position with authority demands the implementation of Islamic ideology. A non-Muslim (regardless of his abilities, sincerity, and loyalty to his country) is believed to be unable and will not work faithfully to achieve the ideological and political goals of Islam.

The political arena and the official public sectors are not the only areas in which non-Muslims are not allowed to occupy positions of 
authority. A Muslim employee working in a company wrote in a letter "If it is permissible for a Muslim owner (of a company) to give authority to a Christian over a Muslim?" (Al-Muslim Weekly; Vol. 8; issue No. 418; Friday $2,5,1993)$.

In response to this letter, three prominent Muslim scholars expressed their legal opinions: Sheikh Manna` K. Al-Qubtan, professor for advanced studies at the School of Islamic Law in Riyadh, stated that: Basically, nonMuslim orders against Muslims are not allowed, because God Almighty says: 'Allah will never give way to unbelievers (i.e. Christians) to destroy (other translation: have authority over) believers (Muslims) )' \{Surah 4:141\}. Because Allah - praise be to Him - has exalted Muslims to the highest level (over all human beings) and has preordained for them strength, through virtue of the Qur'anic text in which God Almighty says: 'Power belongs only to Allah, for His Messenger (Muhammad) and for the believers' \{Sura 63:8\}.

Therefore, the authority of non-Muslims over a Muslim is not in accordance with these two verses, considering that Muslims must submit and obey whoever has power over them. Thus, Muslims are inferior to him, and this should not happen to Muslims.

Dr. Salih Al-Sadlan, professor of Sharia at the School of Islamic Law, Riyadh, quotes the same verses and adds that it is not permissible for an infidel (in this case a Christian) to have authority over a Muslim whether it is in the private or public sector. Such acts: Contain contempt for Muslims and exalt unbelievers (Christians). This infidel will exploit his position to humiliate and humiliate the Muslims who work under his government. It is recommended that the owner of the company fear God Almighty and only give authority to Muslims over other Muslims. Also, the government should stipulate that an infidel cannot take office if a Muslim is deemed capable of giving orders. Our advice to business owners is to remove these infidels and replace them with Muslims."

In his response, Dr. Fahd Al-'Usaymi, professor for Advanced Studies in Islamic Studies at Teachers' College in Riyadh, suggests that the Muslim who owns the company should look for better Muslim employees than the Christian (the Manager), or equal to him or even not very qualified but can be trained to have the same skills as the Christian. It is not permissible for a Christian to rule over a Muslim because of the general evidence that confirms the superiority of a Muslim over another. Then he 
quotes Sura 63:8 and also Sura 58:22 as follows: You will not find a people who believe in Allah and the Hereafter, loving one another with those who oppose Allah and His Messenger, even if they are fathers, or children or brothers or their families.

'Usaymi claims that under authority, a Christian will force a Muslim to please him and humble himself towards this infidel in the hope of getting a little of what he has. Again this confirms the existing evidence. Then he relates it to the story of the second Umar Ibn Al-Khattab Khalif, who was dismayed by one of his governors who appointed a Dhimmi as treasurer, and said: "Have women's wombs become barren so that they only give birth to this person?" Then 'Usaymi added: Muslims should fear God and their Muslim brothers and sisters and train them... because honesty and piety to God are, in fact, in Muslims, different from infidels (Christians) who are, in fact, dishonest and dishonest, fear God.

Does this mean that a Christian who owns a business cannot employ a Muslim? Even worse, does this mean that a Dhimmi, despite his unmatched qualifications, cannot be appointed to a proper position where he can serve his country to the best of his ability? These questions demand answers.

\section{Freedom of Expression}

Mawdudi, more lax than most Muslim scholars, gave a revolutionary opinion when he emphasized that in an Islamic state: All non-Muslims will have freedom of conscience, opinion, expression and assembly; the same as those enjoyed by Muslims, subject to restrictions as imposed by law on Muslims (Al-Maududi, 1990:198).

Mawdudi's views are not accepted by most schools of Islamic law, especially with regard to freedom of expression such as criticizing Islam and the government. Even in a country like Pakistan, Mawdudi's own homeland, it is illegal to criticize the government or head of state. Many political prisoners are imprisoned in Pakistan and in many Islamic countries. Throughout history, except in a few cases, not even Muslims have been given the freedom to criticize Islam without being persecuted or sentenced to death. Especially for a Dhimmi; he cannot get away with criticizing Islam. 
In Mawdudi's statement, the term "boundaries" is defined vaguely. If it is defined literally, you will find, in the final analysis, that it tightly controls and limits any criticism of the Islamic faith and government.

Furthermore, how can the Zimmis express the positive aspects of their religion if they are not allowed to use the media or advertise themselves on radio or television? Perhaps what Mawdudi meant by his proposal to allow such freedom to the Dhimmis was only for themselves. Otherwise, they must submit to punishment. However, Muslims are allowed, under Sharia (law) to propagate their faith among all religious sects without any restrictions.

\section{Muslims and the Dhimmi}

The relationship between Muslims and the Zimmis is divided into two categories, namely what is forbidden/forbidden and what is permissible.

Which is forbidden. A Muslim is forbidden to:

a) Imitating the clothes and behavior of the Dhimmis.

b) Attending the festivals of the Zimmis or supporting them in any way that may give them power over the Muslims.

c) Rent out his house or sell his land for the construction of churches, temples, liquor stores, or anything that can benefit the Zimmi faith.

d) Doing any work for the Dhimmis i.e. work that will benefit their faith such as building a church building.

e) Make a donation to a church or temple.

f) Carrying any vessels containing wine, working in wine-producing premises, or transporting pigs.

g) Calling the Dhimmis with titles or titles such as: "my master" or "my lord".

Which is allowed. A Muslim is allowed to:

a) Supporting the Dhimmis financially, giving money that would not be used to violate Islamic law such as buying wine or pork.

b) Giving purchase rights (ie priority in buying property) to their Dhimmi neighbors. The Hanbili group did not agree on this.

c) Eat the food provided by the People of the Book. 
d) Comforting the Dhimmis who are sick or in mourning. Muslims are also allowed to accompany and accompany the burial ceremony at the cemetery, but he must walk in front of the coffin, not behind it, and he must leave before the body is buried.

e) Congratulations to the Dhimmis on marriage, the birth of a child, returning from a long journey, or recovering from an illness. However, Muslims are warned not to say any words that signify acceptance of the Zimmis belief, such as: "May Allah exalt you," "May Allah honor you," or "May Allah give victory to your religion".

\section{CONCLUSION}

This study shows us that non-Muslims are not seen as citizens by any Islamic country, even if they are natives of that country. To say otherwise is to cover up the truth. Justice and equality demands that Christians, Hindus, Buddhists, Melanesians, Turks, or Arabs be treated the same as other citizens in their own country. He is entitled to enjoy the same privileges as a citizen regardless of religious affiliation.

\section{REFERENCESE}

Abdullah, Najih Ibrahim Bin, (1988) The Ordinances of the People of the Covenant and the Minorities in an Islamic State, Balagh Magazine, Cairo, Egypt, Volume 944, May 29, 1988; Volume 945, June 5, 1988.

Al Muslimun, Vol. 8; issue No, 418; Friday 2, 5, 1993.

Al-Maududi, A. A. (1990). Hukum dan Konstitusi Sistem Politik Islam. Bandung : Mizan.

Doi, `Abdur Rahman I. (1984). Shari`a: The Islamic Law. London UK: Taha Publishers

Esposito, J. (1983). Voice of Resurgent Islam. New York: Oxford University Press.

Esposito, J. (1984). Islam and Politics. New York: Syracuse University Press.

Mawdudi, S. Abul 'Ala' (1982) The Rights of Non-Muslims in Islamic State. Lahore, Pakistan: Islamic Publications, LTD. 
Muraghi, Abdullah Mustapha (1986). Islamic Law Pertaining to Non-Muslims. Cairo: Library of Letters 